\title{
Cadmium and lead in soils and crops from allotment gardens in the Netherlands
}

\author{
P. van Lune (Institute for Soil Fertility, P.O. Box 30003, 9750 RA Haren (Gr.), \\ Netherlands
}

Received 19 January 1987; accepted 27 March 1987

\begin{abstract}
Soils and crops from 57 allotment gardens in possibly contaminated areas were analysed for $\mathrm{Cd}$ and $\mathrm{Pb}$. The median $\mathrm{Cd}$ and $\mathrm{Pb}$ concentrations in the soil samples were higher than those in normal Dutch soils used for arable farming and horticulture. $\mathrm{Cd}$ and $\mathrm{Pb}$ concentrations in the crops were rather normal.

Key words: vegetable garden, $\mathrm{Cd}, \mathrm{Pb}$, soil, crop, Netherlands, contamination.
\end{abstract}

Introduction. There are about one million vegetable gardens in the Netherlands. They are in use by $30 \%$ of the families in the country (Anon., 1985). Mostly the vegetable gardens either belong to private houses or are situated in groups on allotments. The products of these gardens constitute an important part of the diet of many people. It is therefore important to know if these products present any health hazard to consumers.

Increased $\mathrm{Pb}$ contents were observed in crops from gardens in a number of towns in England (Jones \& Thornton, 1983; Davies et al., 1983), in the USA (Spittler \& Feder, 1979), in Germany (Alt et al., 1982) and in gardens adjacent to highways in the Netherlands (Projectgroep Lood in Volkstuinen, 1982). In urban areas (England) contamination of the soil with metals seems to originate from soot emission by chimneys resulting from turning coal (Purves, 1985). Pb-containing exhaust gases from motorized traffic increased $\mathrm{Pb}$ contamination in these areas in the 20 th century.

To obtain some idea about possible contamination with $\mathrm{Cd}$ and $\mathrm{Pb}$ of vegetable gardens in the Netherlands, soils and crops from 57 allotments, situated in possibly contaminated areas, were analysed for these elements.

Materials and methods. The investigation was conducted in the period 1981-1984 on 57 allotments which were assumed to be contaminated with $\mathrm{Cd}$ and/or $\mathrm{Pb}$ because of their position near highways or metal-emitting industries or because of previous use of the land on which the allotments are situated. Some allotments were investigated for more than one year. The growers were asked to grow crops for the investigation in about 20 randomly distributed gardens per allotment. In 1981 lettuce and sometimes endive were cultivated, and in 1982-1984 lettuce, carrots, curly kale and sometimes endive. In principle all crops were grown on all gardens. In each allotment samples of the soil, layer $0-20 \mathrm{~cm}$, and crops were taken in duplicate. Some- 
times one sample was taken when the crops to be sampled were lacking in quality and quantity. The soil samples were taken from the same spots as the crop samples (mostly lettuce). The edible parts of the crops were rinsed with tap water and analysed for $\mathrm{Cd}$ and $\mathrm{Pb}$. The total $\mathrm{Cd}$ and $\mathrm{Pb}$ contents of the soil samples were also determined.

Results. The respective median $\mathrm{Cd}$ and $\mathrm{Pb}$ concentrations in the soil samples (Table 1) were 1.5 and 2.5 times as high as those found by Wiersma et al. (1986) in normal Dutch soils used for arable farming and horticulture. In normal Dutch peat soils and loess soils the mean $\mathrm{Cd}$ concentrations are higher than in clay soils and the mean $\mathrm{Pb}$ concentration in peat soils is higher than in sandy soils and clay soils (van Driel \& Smilde, 1982). An increase of the median $\mathrm{Cd}$ and $\mathrm{Pb}$ concentrations in the soils of the allotments was mainly found in sandy clay and clay soils. In $14 \%$ and $30 \%$ of the investigated allotments a substantial increase in soil $\mathrm{Cd}$ and $\mathrm{Pb}$ was found, respectively ( $\mathrm{Cd}$ and $\mathrm{Pb}$ concentrations higher than $1 \mathrm{mg} \mathrm{kg}^{-1}$ and $100 \mathrm{mg} \mathrm{kg}^{-1}$, respectively). Median $\mathrm{Cd}$ concentrations in lettuce, carrots, curly kale and endive, grown in market gardens were $0.04,0.03,0.02$ and $0.02 \mathrm{mg} \mathrm{kg}^{-1}$ fresh weight, respectively (Wiersma et al., 1986). Median $\mathrm{Pb}$ concentrations amounted to 0.09 , $0.04,0.54$ and $0.07 \mathrm{mg} \mathrm{kg}^{-1}$ fresh weight, respectively. Median Cd concentrations in lettuce, carrots and curly kale and median $\mathrm{Pb}$ concentrations in lettuce and carrots (Table 1) were comparable to those found on market gardens. Median Cd concentration in endive was 4 times as high as that in commercial crops and median $\mathrm{Pb}$ concentrations in curly kale and endive were 2 and 2.5 times as high, respectively. Only in one sample of endive was the tentative maximum acceptable Cd concentration in commercial crops (Klitsie, 1983) exceeded and that for $\mathrm{Pb}$ in one sample of curly kale. In establishing the tentative maximum $\mathrm{Cd}$ and $\mathrm{Pb}$ concentrations for commercial crops one of the considerations was that a product with a possibly high

Table 1. Cd and $\mathrm{Pb}$ concentrations in soils and crops from allotment gardens in possibly contaminated areas.

\begin{tabular}{|c|c|c|c|c|c|c|c|c|c|}
\hline \multirow[t]{2}{*}{$\begin{array}{l}\text { Soil } \\
\text { or crop }\end{array}$} & \multirow{2}{*}{$\begin{array}{l}\text { Number of } \\
\text { sampled } \\
\text { allotments }\end{array}$} & \multicolumn{4}{|c|}{$\begin{array}{l}\text { mg Cd per kg dry soil or } \\
\text { per kg fresh weight crop }\end{array}$} & \multicolumn{4}{|c|}{$\begin{array}{l}\text { mg Pb per kg dry soil or } \\
\text { per kg fresh weight crop }\end{array}$} \\
\hline & & $\min$. & $\max$ & mean & median & $\min$. & $\max$ & mean & median \\
\hline Sand & 13 & 0.15 & 0.75 & 0.33 & 0.30 & 15 & 326 & 49 & 25 \\
\hline Sandy clay & 27 & 0.19 & 2.61 & 0.79 & 0.63 & 17 & 274 & 101 & 79 \\
\hline Clay & 7 & 0.34 & 3.17 & 1.18 & 0.77 & 64 & 325 & 138 & 140 \\
\hline Loess & 6 & 0.43 & 1.00 & 0.63 & 0.58 & 28 & 105 & 47 & 37 \\
\hline Peat & 4 & 0.56 & 0.98 & 0.82 & 0.88 & 22 & 85 & 47 & 40 \\
\hline All soils & 57 & 0.15 & 3.17 & 0.72 & 0.61 & 15 & 326 & 85 & 61 \\
\hline Lettuce & 51 & 0.01 & 0.18 & 0.05 & 0.05 & 0.05 & 0.20 & 0.09 & 0.08 \\
\hline Carrot & 39 & 0.02 & 0.17 & 0.06 & 0.04 & 0.01 & 0.24 & 0.06 & 0.05 \\
\hline Curly kale & 26 & 0.02 & 0.08 & 0.04 & 0.03 & 0.24 & 2.54 & 1.03 & 0.91 \\
\hline Endive & 15 & 0.03 & 0.23 & 0.09 & 0.08 & 0.06 & 0.29 & 0.16 & 0.19 \\
\hline
\end{tabular}


$\mathrm{Cd}$ or $\mathrm{Pb}$ concentration - but still lower than the tentative maximum concentration - is counterbalanced by a product with a low $\mathrm{Cd}$ or $\mathrm{Pb}$ concentration in the diet. However, when the $\mathrm{Cd}$ or $\mathrm{Pb}$ concentration of one crop in a garden is raised, the concentration will generally also be higher in other crops in this garden. This should be taken into account when the tentative maximum acceptable $\mathrm{Cd}$ and $\mathrm{Pb}$ concentrations for commercial products are applied to vegetable garden products.

Conclusions. The median $\mathrm{Cd}$ and $\mathrm{Pb}$ concentrations in soils of allotment gardens in possibly contaminated areas were higher than those in normal Dutch soils used for agriculture and horticulture. Median $\mathrm{Cd}$ and $\mathrm{Pb}$ concentrations in the crops from these allotments were rather normal. Only the median $\mathrm{Cd}$ concentration in endive and median $\mathrm{Pb}$ concentrations in curly kale and endive were higher than those found in commercial farming. Because crops from allotments in possibly contaminated areas have rather normal $\mathrm{Cd}$ and $\mathrm{Pb}$ concentrations it is reasonable to assume that in general $\mathrm{Cd}$ and $\mathrm{Pb}$ concentrations in crops from vegetable gardens in the $\mathrm{Ne}$ therlands are normal. However, alertness for exceptional cases is required.

Acknowledgements. Thanks are due to Mr S. Bommeljé and Ing. J. W. M. Janssen of the Central Advisory Department (CAD) for Soil, Water and Fertilizers (Arable Farming and Horticulture), Wageningen, who collected the samples.

\section{References}

Alt, D., B. Sacher \& K. Radicke, 1982. Ergebnis einer Erhebungsuntersuchung zur Nährstoffversorgung und Schwermetallbelastung von gemüsebaulich genutzten Parzellen in Kleingärten. Landwirtschaftliche Forschung, Sonderheft 38: 682-692.

Anon., 1985. De moestuin in West-Duitsland, Groenten + Fruit 40: 16-17.

Davies, B. E., W. L. Davies \& N. J. Houghton, 1983. Lead in urban soils and vegetables in Great Britain. In: Proceedings International Conference on 'Heavy metals in the environment' (September 1983, Heidelberg), Vol. II, p. 1154-1157. CEP-Consultants, Edinburgh.

Driel, W. van \& K. W. Smilde, 1982. Heavy-metal contents of Dutch arable soils. Landwirtschaftliche Forschung, Sonderheft 38: 305-313.

Jones, T. H. \& I. Thornton, 1983. Lead, zinc, cadmium, copper and nickel in British urban soils: uptake into vegetables and implications to public health. In: Proceedings International Conference on 'Heavy metals in the environment' (September 1983, Heidelberg), Vol. II, p. 1178-1182. CEP-Consultants, Edinburgh.

Klitsie, C. G. M., 1983. Ontwerpnormen voor cadmium, lood en kwik. Bedrijfsontwikkeling 14: 502504.

Projectgroep Lood in Volkstuinen, 1982. Lood in volkstuinen: een risico-evaluatie. L.H. Wageningen, Vakgroep Luchthygiëne en -verontreiniging, Rapport R-50; Vakgroep Gezondheidsleer, Verslag 1982-121.

Purves, D., 1985. Trace-element contamination of the environment. Elsevier, Amsterdam etc., 243 pp.

Spittler, Th. M. \& W. A. Feder, 1979. A study of soil contamination and plant lead uptake in Boston urban gardens. Communications in Soil Science and Plant Analysis 10: 1195-1210.

Wiersma, D., B. J. van Goor \& N. G. van der Veen, 1986. Cadmium, lead, mercury and arsenic concentrations in crops and corresponding soils in The Netherlands. Journal of Agricultural and Food Chemistry 34: 1067-1074. 
This synopsis is based on a report entitled 'Cadmium en lood in grond en gewas van moestuinen in Nederland', Institute for Soil Fertility, Haren (Gr.), Netherlands. 18 pp., 5 tables, 14 refs. Dutch.

Available as paper copy (order R073P, free) from: NARD, clo Pudoc, P.O. Box 4, 6700 AA Wageningen, Netherlands (telex $45015 \mathrm{blhwg}$ ). 